\title{
DATABASE SECURITY AND THE PROBLEM OF POLYINSTANTIATION: A MORAL SCRUTINY
}

\author{
Mikko T. Siponen \\ University of Oulu, Department of Information Processing \\ Science, Linnanmaa, P.O.BOX 3000, FIN-90014 Oulu University, FINLAND. \\ E-mail:Mikko.T.Siponen@oulu.fi
}

\begin{abstract}
In the area of computer security the problem of polyinstantiation is widely recognized. The research on polyinstantiation can be considered morally questionable, since it involves lying. This being the case, a moral scrutiny on the problem of polyinstantiation is warranted. The morality of polyinstantiation shall be critically analysed from the viewpoint of a moral philosophical framework. The moral philosophical framework used includes 1) Kantian ethics, 2) the universality theses advocated by Hare, Rawls, Gewirth, Jewish-Christian ethics, and Confucian ethics, 3) utilitarianism, and 4) Theory of Information Ethics (IE) by Floridi. The result of this analysis suggests that research and practice on polyinstantiation is morally questionable, at least in the light of the chosen moral philosophical theories. The aim of the paper is not, however, to deem polyinstantiation as morally wrong altogether, but to provide researchers and practitioners with tools and insights for analyzing the morality of polyinstantiation in different cases. Moreover, the results suggest that, as far as polyinstantiation is concerned, traditional ethics theories seem to be at least as adequate as IE.
\end{abstract}

\section{INTRODUCTION}

Information security solutions have an increasing role in the information age, given that security solutions technically ensure or deny access to information. This being the case, the moral scrutiny of security actions cannot be overlooked - particularly when security techniques are developed and used to provide false information. Polyinstantiation - which is a central research issue in database security (e.g., Lunt, 1991; Pernul, 1992; Jajodia \& Sandhu, 1995; Ellmer et al., 1995; Gollman, 1999) - is such a solution (developed to provide false information). It is developed for maintaining different "realities" or cover stories to different user groups, and therefore it involves lying to users. In other words, users who have, say top secret clearences ${ }^{4}$, are allowed to see the "true" (top secret) information within databases, while people who have lower security clearences (e.g., secret, classified, etc) are only allowed to see false information. Even though the issue of polyinstantiation is a well-known research issue in database/computer security and is morally questionable due to the lying involved, it has not yet been analyzed from a moral point of view. This might be partly due to the conventional moral notion ${ }^{5}$ of those working in the field, that security activities are morally good per se (i.e., security people are the good guys). Also, the blind technocratic view that "the scientist accepts uncritically the goal A, without questioning it or without understanding his or her moral responsibility in producing tools for reaching A" (Niiniluoto, 1993 p. 17) seems to prevail in the field.

The aim of this paper is to analyze the morality of polyinstantiation. The issues of polyinstantiation will be analyzed through ethics theories including Kantian ethics and the impartial universality thesis advocated by Hare $(1963 ; 1981)$ and Rawls (1972). As the universality thesis plays a role in many other ethics theories (from philosophy to religion-based), an analysis in the light of it may satisfy, at least in that respect, the requirements of the advocates of such theories. Moreover, the issues will also be reflected through the theory of information ethics of Floridi (1999), which has not been critically analyzed, and utilitarianism. Conceptual analysis in terms of Järvinen (1997) is used as the research approach to yield these results. An early version of this paper is presented at the AMCIS'2000, Long Beach, CA, USA.

The paper is organized as follows. In the second section, the framework for the analysis is presented. In section 2.1 , the ethics framework is succinctly considered and reasoned, and in section 2.2 polyinstantiation will be briefly presented. In the third section, the morality of polyinstantiation will be analysed. In the fourth section, certain implications for research and practice will be discussed. In the fifth section, the key issues of the paper will be summarised.

\section{The framework for the analysis}

\footnotetext{
${ }^{4}$ Herein the security level (e.g., top secret, secret, confidential) of the users.

5 The conventional (moral) notion refers to a situation where a person unquestionably conforms to the standards of a group or society (Taylor, 1975; Hare 1981)
} 
The ethics framework

THE SELECTED ETHICS THEORIES ARE DESCRIBED BELOW (TABLE 1). TABLE 1. SELECTED ETHICS DOCTRINES

\begin{tabular}{|c|c|c|}
\hline $\begin{array}{l}\text { Theory/ } \\
\text { Thesis }\end{array}$ & Objectives & Weaknesses and objections \\
\hline Kant & $\begin{array}{l}\text { 1) sense of duty; 2) } \\
\text { "impartial" universality } \\
\text { principle; 3) the rule of } \\
\text { human dignity; }\end{array}$ & Partial universality thesis \\
\hline Utilitarianism & Maximize happiness & $\begin{array}{l}\text { Why is happiness the key issue? } \\
\text { Utilitarianism does not count on the } \\
\text { preferences of individuals. Leads to } \\
\text { negative utilitarianism (which leads to } \\
\text { absurd conclusions) }\end{array}$ \\
\hline $\begin{array}{l}\text { Rawls' "Veil of } \\
\text { ignorance" and Hare's } \\
\text { universalisability of } \\
\text { moral judgment }\end{array}$ & $\begin{array}{l}\text { Universality thesis: "What } \\
\text { if everybody were to do } \\
\text { that?" }\end{array}$ & Our decisions are always subjective. \\
\hline Agape & $\begin{array}{l}\text { One should perform loving } \\
\text { or caring actions towards } \\
\text { fellow people }\end{array}$ & Love can be blind and irrational \\
\hline $\begin{array}{l}\text { The theory of } \\
\text { information ethics }\end{array}$ & $\begin{array}{l}\text { Four moral laws; Principle } \\
\text { of ontological equality }\end{array}$ & $\begin{array}{l}\text { The claim that one needs to respect all } \\
\text { entities leads to difficulties. }\end{array}$ \\
\hline
\end{tabular}

\section{Kant's R1 and R3}

Kantian ethics is a traditional theory, three points from which will be presented (e.g., Raphael, 1994; Warburton, 1996). The first is the sense of duty, the second the thesis of universality (i.e., act only on maxims that you want to be universal laws), and the third is the rule of human dignity (treat other people always as an end, never only as a means). These will be referred to as Kantian requirements R1, R2 and R3. Variations of R2 have been widely used in Jewish-Christian ethics (e.g., the Golden Rule in the case of Christian ethics), Confucian ethics, universal prescriptivism (Hare, 1981), and Rawls' theory of justice (1972), etc.

\section{Agape and Kant's R1}

Kantian R1 has raised a debate on whether a sense of duty is relevant as a qualifier of the rightness of an action. Actions stimulated by a feeling of love are not acceptable, for example, as love can be blind, and therefore, according to Kant, confuse rational thinking. In this respect, Kant's doctrine contradicts some different doctrines and interpretations of Christian ethics, where love (agape) plays an important role in determining if an action qualifies as being morally acceptable (e.g., Hare, 1992a, 1992b; Jackson, 1999; Macquarrie and Childress, 1986 p. 354-356; Thomas, 1955). Agape means, for example, that "you shall love you neighbor as yourself" where neighbor means everybody (Jackson, 1995 p. 3) and can be regarded as a kind of universality thesis.

However, by looking at an objection to Kant's ethics by Floridi (1999), we may see that Kantian R1 has its relevance. Floridi argues that different sorts of harmless vandalism such as a boy stoning abandoned cars (Floridi, 1999 p. 53-54) cannot be deemed morally blameworthy by using the Kantian argument. First, Floridi argues that "its ends/means maxim is inapplicable" (Floridi, 1999 p. 54). Secondly, the possible problem of the universality thesis, if applied to this case, is its possible bias towards subjective decisions (see below), resulting in that the mentioned vandalism would be accepted. However, Floridi seems to have forgotten Kantian R1. Namely, it seems to be clear that Kantian ethics regards this action (the boy stoning the abandoned cars) as morally wrong due to the requirement of a sense of duty (R1): its is difficult to imagine that a boy's sense of duty (in the Kantian sense), given that the boy is interested in behaving morally right, includes such stoning of the abandoned cars.

\section{Kant's R2 and other Universality theses by Hare, Rawls}

One weakness of Kantian R2 (act only on maxims that you want to be universal laws) is its lack of impartiality. It seems to be possible to formulate maxims that are not impartial, when impartiality would bring more equality. 
For example, the adding of different "epithets" such as age and status to the maxims to be universalised (in a Kantian sense) can result in a partiality that can be difficult to justify. One might form a maxim, say, putting his/her name or age in it (also presuming that this also satisfies the first and the last Kantian requirements), thereby allowing some privileges to people whose age and name are different from these, for instance. Therefore, to avoid a weakness of this kind, the universality thesis used hereafter will be formulated in an "impartial" manner (although no universality thesis is really impartial) without the aforementioned qualifiers, which are likely to be irrelevant with respect to the morality of an action (see Hare, 1989; Kukathas \& Pettit, 1990; Siponen \& Vartiainen, 2002 for more). Hence, if we consider whether action X is allowed or not in the light of the "impartial" universality thesis, we need to ask whether we would accept that everybody were allowed to do X (in similar situations).

An interesting objection which seems to apply to both partial and impartial forms of the universality thesis has been outlined by MacIntyre (1986). He sees that the universality thesis involves a kind of hubris, given that an individual universalising a judgment functions also as a 'universal legislator', and that judgment applies to all (thus, it is not supererogative, but the action in question is required). Hence, MacIntyre ponders who has a right to be such a universal legislator? The idealistic idea of MacIntyre (1986) has a weakness. Given that all actions are supererogative, i.e., not necessary, we are in trouble in practical life. To claim that the avoidance of killing an innocent person is also supererogative, i.e., the avoidance of the killing is not compulsory, but "virtuous", is not a very persuasive claim.

\section{The theory of Information Ethics}

The theory of Information Ethics (IE) is a novel approach by Floridi (1999) that has not been applied much as of yet, and therefore, the reader should consider the author's interpretation of it with a certain amount of circumspection. A key element of IE is the concept of information entity. Every existing entity is a consistent packet of information and does not contain a contradiction in itself in terms of IE, since they are entities in the infosphere, needs to be respected in a certain sense; one should let the entities develop in their natural ways. The latter view is called the ontological equality principle (Floridi, 1999 p. 44). We see this principle of ontological equality as an extended version of thesis of "equal regard" in Christian ethics. The thesis of "equal regard" means that we should express same respect to all people irrespective who they are (e.g., Outga, 1972) This ontological equality principle of IE becomes interesting from the point of view of anti-virus activity. It seems that a computer virus is regarded as an information entity in terms of IE: it is a consistent packet of information. Being so in the light of the ontological equality principle, computer viruses (being information entities) should be let "develop in a way which is appropriate to their nature" (Floridi, 1999 p. 44). Thus, if spreading viruses, for example, is an action which is appropriate to their nature, anti-virus activity may be wrong, at least from this point of view.

Additionally, IE has been criticized on pragmatic grounds, namely the process it uses for measuring the amount of entropy is a "cold" mechanistic calculation (Siponen \& Vartiainen, 2002). They view that ordinary people may not easily associate entropy with wrongdoing. For that reason, IE may be less suitable for dealing with problems of moral motivation and moral distance than universality theses (e.g., the Golden Rule). To solve ethics dilemmas, for example, IE provides four principles (in order of increasing moral value). Three of them are as follows) I) an action ought not cause entropy; ii) entropy ought be prevented and III) entropy ought to be removed (the fourth principle will not be applied here).

Let consider these principles of IE from the viewpoint of anti-virus activity. Anti-virus activity seems to violate the null law, given that the action of deleting viruses increases entropy (also creation and distribution of viruses may satisfy the third law). Of course, a malicious computer virus may also violate the null law. In that case, one may like to interpret IE in such a way that the amount of entropy can be calculated. The final moral judgment would be the action that constitutes the least amount of entropy: It is likely that the anti-virus activity is the less harmful action.

\section{Utilitarianism}

Utilitarianism holds that under any given circumstances the action which produces the greatest amount of happiness on the whole is the right one. This involves taking into account everyone whose happiness is affected by the action in question. According to utilitarianism, we may 1) calculate the happiness of all beings who are capable of pleasure and pain and whose feelings are affected by our action; 2) or confine our concern to human happiness. The weakness of utilitarianism relates to its incapability of taking into account individual preferences. Moreover, it does not take into account the "quality" of preferences, e.g., should we take the preferences equally into account. Are there preferences that are "sick" or inherently bad, and therefore should not be counted? 
Additionally, utilitarianism may lead to negative utilitarianism, which in turn leads to absurd conclusions (e.g., Warburton, 1996). Finally, the use of utilitarianism to solve one's ethics conflicts is difficult. How can one person take into account everyone's preferences? It would require a popular election.

The reader may wonder why certain theories such as intuitionism (we have an intuition that is capable of discerning what is right and wrong), cultural relativism (e.g., moral values are culturally dependent: what is considered wrong in one culture may be acceptable in another culture) and emotivism (moral views are purely an expression of our emotions) are not applied. The reason is that we consider these theories as unfruitful with respect to moral thinking. They do not help us in conflicting situations and involve inconsistencies. Say (case 1) that according to the intuitions of person $\mathrm{X}$ polyinstantiation is acceptable, and according to the intuitions of person $\mathrm{Y}$ it is not acceptable. Similarly (case 2), presume that in the culture of person X polyinstantiation is acceptable, and in the culture of person $\mathrm{Y}$ it is not acceptable. What can be concluded from cases 1 and 2? Is polyinstantiation right or wrong? Which one, $\mathrm{X}$ or $\mathrm{Y}$ is right? The possible reply that both $\mathrm{X}$ and $\mathrm{Y}$ are equally right is not a persuasive answer for two reasons. First, how can the same action in the same situation be at the same time right and wrong? Secondly, the answer that both $\mathrm{X}$ and $\mathrm{Y}$ are right does not give us much help when we are considering whether polyinstantiation is morally right or wrong, or whether we should apply it. Thirdly, theories of intuitionism, emotivism and relativism do not give us a rational account of why this action (or any action) is right or wrong, given that we do not recognize arguments such as "because this is my intuition/emotions/cultural view" as adequate reasons to act (or avoid an action). It is a matter for sociology to study what the personal intuitions (preferences), emotions and cultural preferences are. But such sociological facts (e.g., what people consider as right/wrong) do not indicate what is right and wrong, i.e., how we ought to act.

Emotivism, as advocated by Stevenson (1944), i.e., stating that our moral concerns are nothing but expressions of our emotions, is confronted with similar problems. For example, ethics cannot be purely an expression of emotions, otherwise ethics discussion would consist of different sounds, such as grunts, and all moral argumentation would become difficult (e.g., Warburton, 1995). Moral values cannot be discussed or contemplated without reference to emotions, although emotions per se are inapt justifications for actions.

\section{Polyinstantiation}

Such conventional requirements of information security as confidentiality, integrity, and availability in the area of databases have raised rather interesting concerns. One of the concerns that will be explored here is the need for maintaining different concepts of reality between different classes of users. This requirement relates to databases which are referred to as being multilevel secure (here the aim is not to consider whether they are secure in this way or how successfully they meet the security requirements). A database system supporting many levels of clearances such as top secret (TS), secret (S) and confidential (C) is called a multilevel database system. One of the simplest reasons for having such a system is to ensure that users who have a clearance for seeing secret level information are able to view only that level, but not information of the top secret level, for instance. Such a system, if it satisfies the requirement just mentioned, can be said to be multilevel secure (MLS). This requirement has been further tightened to maintain different realities, in other words to support lying. This problem is technically termed as the problem of polyinstantiation. A relation can be said to be polyinstantiated when it has two or more tuples with the same primary key. The approaches to solving this problem technically can be categorised as entity or attribute polyinstantiations (Jajodia \& Sandhu, 1995) and as they both similarly encompass lying, their technical differences will not be discussed here.

Table 1 models an imagined MLS relational database system where the earlier mentioned classification of different user level clearances has been implemented. Let us assume that this example describes a relation consisting of information about a space shuttle going towards satellite $\mathrm{X}$ for military purposes, and this real objective can only be viewed by the people who have top secret (TS) level clearances (Table 2).

Table 2. An example of polyinstantiation.

\begin{tabular}{|l|l|l|}
\hline Name & Destination & Aim \\
Space shuttle TS & Satellite X & Military \\
Space shuttle S & Satellite X & Scientific \\
Space shuttle C & Satellite Y & Scientific \\
\hline
\end{tabular}

This example (Table 2) shows the lying involved, as the user having a confidential level clearance $(\mathrm{C})$ is mislead to believe certain false information. That is to say, the confidentiality level users $(\mathrm{C})$ are being convinced by the owners of the system/TS people that the destination of the journey is satellite $\mathrm{Y}$ and the objective is purely scientific. 


\section{THE MORAL STATUS OF POLYINSTANTIATION}

The question whether polyinstantiation is morally wrong in general cases and in three particular cases (A, B, C) will be considered in the light of selected ethics theories (Kantian ethics, universality theses by Hare, Rawls, etc, utilitarianism, agape and the theory of information ethics).

\section{Polyinstantiation in general cases}

Is polyinstantiation acceptable in general cases?

\section{Case A: Lying to maintain stability}

Let us assume (as possible argument A) that lying with respect to the security of security solutions is done in order to maintain a human life that avoids disturbance (whatever its exact amount is), since the expression of truth would (momentarily) increase the amount of disturbance or even chaos. This argument is chosen since it is interesting from the point of view of IE.

\section{Case B: An appeal to private information}

One may try to justify polyinstantiation by appealing to the presumed right for informational privacy or ownership of information. For example, one may first argue that databases consist of "private" information, since the information stored in databases is input by the owner of the system. Hence, the information is owned by the owner of the systems. Therefore, one may argue that this "private" information or owned information should be under the control of the owner. Moreover, this control includes that one should have "the right" to hide (parts of) the owned/private information (that is "true information, for instance), and furthermore the right to decide what is "the public side" (herein "false information"). The weakness of this argument is that it is not obvious that the owners of the systems (e.g., an organization) really own all the information - and even if they do own it, it does not follow that the owners have so full a control over it that it includes manipulation of the information.

Even though we might appreciate private information, even privacy has its limits. If this were not the case, ethics dilemmas with respect to privacy would not exist. For this reason, e.g., to see whether one's privacy claims are justified, we need ethics theories.

\section{Case C: It can be used for good purposes}

An often used justification for basic scientific research is to claim that the techniques being developed, even those associated with weapons research, can also be used for morally good purposes. Therefore, the development per se, one can argue, is an amoral matter, but its application or further use is not. The aim of this paper is not to consider whether bombs, for instance, can be reasonably justified in that manner, but rather whether the techniques of polyinstantiation providing lying can be used for morally good purposes? That would perhaps be the case when such solutions would be implemented to prevent a murder of innocent people, for example if a murderer insinuates him/herself into a system having C-level clearances and is lured into a trap due to false information. It is, however, rather difficult to believe that most of the solutions would be used for those kinds of purposes. It is at least equally presumable that such a solution is provided to cover activities that are morally questionable.

\section{Kantian ethics}

It is often claimed that Kant holds a rather absolute view towards lying, as indicated in his doctrine "on a supposed right to lie from altruistic motives" (Kant, 1997). This raises objections about how a society can really work if lying is unacceptable in the situations he describes. However, his view on lying can also be considered in the light of the division of perfect and imperfect duties, in which the latter are required only to some extent, and therefore this latter view, if accepted, is similar to a prima facie duty (Hill, 1971).

Polyinstantiation also seems to violate Kantian R3, since such feeding of false information may not recognize the autonomy of other people. For instance, a person's autonomy may be violated given that his/her decision is made on the basis of false information and the decision would be totally different if the individual were provided with true information. The result of this is that polyinstantion would be wrong according to Kant. All the cases violate Kantian principle of human dignity. 


\section{The universality thesis}

According to Kant, a society cannot be based on a situation where lying is accepted (Kant, 1974 p. 444), and commonly speaking, perhaps many of us would end up with a similar belief after application of the universality thesis: "but what if everyone lied?" Thus, the aforementioned view (the Kantian universality thesis) would likely regard lying as wrong in a general sense. This would perhaps also apply to lying related to polyinstantiation in a general sense.

Argument A is not likely to survive from the point of view of the (impartial) universality thesis: "do you prefer a society where such a activity would be accepted?"). Even though in case A, if telling the truth would instantly increase disorder (let us assume so), we assume that many of us would still choose to tell the 'truth' (as it would be a better option even with small momentary increases of disorder than a situation based on lying).

Argument B is also questionable from the viewpoint of the universality thesis. That is to say, the impartial universality thesis may not support such an activity ("what if everybody were acting in that way?") The third case (C) may be acceptable in the light of the universality thesis provided that we would consider polyinstantiation as a necessary activity in order to avoid some activity that we consider more unwanted (e.g., killing in our example).

\section{Agape}

In addition to the Golden Rule, Christian thinkers may avoid polyinstantiation in all cases since it is difficult to see it as an expression of love (agape).

It is difficult to see that lying in a general sense could be carried out to express love. One may argue that the third case (C) makes an exception. Given that polyinstantiation is necessary for stopping more unwanted activities (that are very anti-loving activities), it can be claimed that polyinstantiation would be acceptable in such a situation.

\section{Utilitarianism}

Whether polyinstantiation is wrong from the utilitarian point of view, can be ascertained by counting the preferences of all people. Lying in a general sense may also not increase our happiness, but if acting honestly maximizes happiness, lying would be morally wrong from the utilitarian viewpoint. For example, If A were the prevailing state of affairs, and further, assuming that disorder due to 'truth' implies unhappiness, the utilitarian view would allow lying. If, on the other hand, truth increased pleasure, the truth should be revealed.

\section{The theory of information ethics}

If, in that case (example A), one applied IE, then lying might be at first sight morally more favorable than telling the truth, given that lying does not increase entropy (consider the null law of IE), but it may also prevent entropy and telling the truth, considering example A, increases entropy. Above it was presumed that lying does not increase entropy at all. If the lying does cause some amount of entropy, however, it may not change the result under consideration, given that telling the truth would increase entropy more than lying. Although in that case both actions may not be morally good (given that they both increase entropy), one should perhaps perform the action (provided that these are the only possibilities) which is perceived better based on the level of entropy. Of course, it is not clear that telling the truth (in situations such as A) would increase entropy at all. The applier of IE, however, might consider lying as morally wrong in case A in the respect that correctability (which is one of the constructionist information properties of the infosphere) is a feature of the infosphere that should be respected. It therefore seems that according to IE we should respect the correctness of information, which lying is most likely not to do. When it comes to the other cases $(\mathrm{B}, \mathrm{C})$, the amount of entropy would be the final factor deciding whether polyinstantiation would be morally acceptable in these situations.

\section{DISCUSSION, LIMITATIONS AND IMPLICATIONS OF THE STUDY}

This study has analyzed the morality of polyinstantiation in the light of ethics doctrines. There may be a few objections to the moral scrutiny of polyinstantiation that are worth discussing. Firstly (A), one may claim that the lying is intuitively seen as morally blameworthy and the issue is therefore obvious. Secondly (B), it may be claimed that research is value-free, as is often viewed among the positivism tradition. Thirdly (C), one may claim that the issue of lying (irrespective of whether research is perceived as value-free or not) can be traced back to the dispute between positivism and anti-positivism - and is therefore more a philosophical issue about the relevance of positivism and anti-positivism, which 1) cannot be settled (making discussion needless), and 2) is not a research issue of the IS community, but philosophers. Fourthly (D), one may argue that polyinstantiation 
should be accepted due to technological determinism, i.e., "technological change is completely and unique determined by internal laws independently of human will" - and all technological possibilities should be realized (Niiniluoto, 1990 p. 181). Fifthly (E), one may claim that many security managers do not care at all whether polyinstantiation is morally wrong or right, and therefore the morality discussion is useless. We shall next consider these five objections.

A) It may be the case that the notion that lying is wrong has been inculcated in many of us through educational systems (as a conventional moral notion), and/or we may consider the imperative "do not lie" as a prima facie duty/principle (following the terminology of Ross (1930) and Hare (1981), respectively) . The crucial question is, however, how do we know whether our beliefs or conventional moral notions are right? And what are the reasons why such lying may be wrong (or right)? Therefore, an analysis of such lying from the viewpoint of theories of ethics will hopefully clarify the moral status of these issues.

B) For the same reasons - given that we want to be sure of whether research, and particularly research with respect to polyinstantiation, is value-free - we cannot avoid the moral scrutiny.

C) We share the view of Hare (1985) that the entry of the disputes between positivism and anti-positivism in moral matters is misleading. It is misleading, since the issue of whether research in polyinstantiation is morally praiseworthy or blameworthy is not epistemological (how we obtain knowledge) nor ontological (what exists), but conceptual analytical (see Hare, 1985). To include the issue of positivism/anti-positivism into a moral inquiry does not clarify, but rather confuses the most important question, namely what are ultimately the right actions. We do not see that the dispute of positivism/anti-postivism is capable of providing any explaining justification one way or another, but at worst it can be used as a pretence to justify actions dogmatically. When it comes to objection $\mathrm{C} 2$ about the relevance of a moral scrutiny of polyinstantiation, let us recall a widely agreed view that IS can be divided into three levels: organizational, conceptual and technical (e.g., Iivari \& Koskela, 1987; Iivari, 1989; Lyytinen, 1987). The moral scrutiny of polyinstantiation is relevant to the IS community since it encompasses the technical, conceptual and organizational levels. Technical solutions are cases in point with respect to the technical level (e.g., see Jajodia \& Sandhu, 1995; Gollman, 1999), and the modeling of security aspects including polyinstantiation (e.g., Pernul, 1992; Ellmer et al., 1995; Pernul et al., 1998) are examples of a conceptual level issue. Finally, the issue of whether polyinstantiation is morally acceptable can be seen at the organizational level (the guidelines/principles of right/wrong conduct are examples of organizational level research).

D) Technological determinism is a naive viewpoint: if something can be done it does not mean that this thing should be done (e.g., Niiniluoto, 1990). We can image several malicious actions that we could do in theory, but it does not follow that we should perform such actions just because they can be done.

E) The issue should be important for managers, as well. Firstly, it is widely agreed that humans are moral beings: most of us want to do the right thing (Taylor, 1975; Hare, 1981; Warburton, 1996). Secondly, employees, public and third parties are likely to hold a more positive view when organizational activities can withstand moral scrutiny. And even if the fifth argument is interpreted as a pragmatic argument - claiming that some managers may see the discussion on the moral status of polyinstantiation as vain - it does not follow that the issue should not therefore be discussed from a moral point of view.

\section{Implications for practice}

The results of this analysis suggest that polyinstantiation is, in general sense, a morally questionable activity. Based on the moral scrutiny of polyinstantiation, we shall formulate a practical guideline for practitioners and researchers.

- Consider whether polyinstantiation/lying can be avoided? Is such lying necessary?

- Consider in which situations polyinstantiation is used. Consider whether it is acceptable in these situations with the help of theories of ethics. For example, when applying the universality thesis, you need to consider the situation and ask: Would you like it if people acted towards you in a similar manner, i.e., would you prefer that people in similar situations lied/provided false information to you?

\section{CONCLUSIONS}

Technical research and "design research" is generally quite applied by nature, resulting in that moral scrutiny cannot be avoided (e.g., Niiniluoto, 1993). Polyinstantiation, a product of technical or design science, is an action that is indeed relevant to consider from the moral point of view: polyinstantiation entails lying. Lying with respect to polyinstantiation was analyzed in the light of different theories of ethics, namely Kantian ethics, the universality thesis (expounded by many ethicist such as Hare and Rawls), the theory of information ethics and utilitarism. It is argued that the activity is morally questionable, at least in light of the used moral philosophical framework. None of the theories gave support for maintaining polyinstantiation in a general sense. Lying violates the Kantian rules of human dignity. IE advocates that information should be true, and most of us 
would not want that everyone in a similar situation would provide us false information (universality thesis), and it is difficult to see it as an expression of love (cf., agape in Christian ethics). Of our cases, the third case (C) was the only one that may be acceptable for polyinstantiation. Assuming that polyinstantiation is necessary for avoiding more negative activities than polyinstantiation, it could be considered acceptable. It is concluded that the traditional theories of ethics (other theories used excluding IE) seem to be as adequate as IE - as far as polyinstantiation is concerned.

WE HOPE THAT THIS ANALYSIS HAS GIVEN NEW INSIGHTS TO PRACTITIONERS AS WELL AS RESEARCHERS, AND THEREFORE PROVIDES VALUABLE INFORMATION ON THE VALUE OF THE RESEARCH ON POLYINSTANTIATION.

\section{REFERENCES}

Ellmer, E., Pernul, G. and Kappel, G. "Object-Oriented Modelling of Security Semantics," Proceedings of the 11th Annual Computer Society Applications Conference (ACSAC'95), 1995, IEEE Computer Society Press.

Floridi, L. "Information Ethics: On the Philosophical Foundation of Computer Ethics," Ethics and Information Technology, (11), 1999, pp. 37-56.

Confucious, (1993), Analects. Translated by R. Dawson. Oxford University Press.

Gollman, D." Computer Security," Wiley \& Sons, UK, 1999.

Hare, R.M. "Freedom and Reason," Oxford University Press, UK, 1963.

Hare, R.M. "Moral Thinking: its levels, methods and point," Oxford University Press, Oxford, UK, 1981.

Hare, R.M. "Ontology in Ethics," In Morality and Objectivity: Essays in Memory of John Mackie (eds): T. Hondrich. Routledge, 1985.

Hare, R.M. "Principles, " In R. M. Hare (eds.): Essays in Ethical Theory, pp. 48-65, Oxford University Press, UK, 1989.

Hare, R.M. "Are There Moral Authorities?" In R.M. Hare (eds): Essays on religion and education, Oxford University Press, Oxford, UK, 1992a.

Hare, R.M. "Euthanasia: A Christian View, " In R.M. Hare (eds): Essays on religion and education, Oxford University Press, Oxford, UK, 1992 b.

Hill, T. E. "Kant on Imperfect Duty and Superegoration," Kant-Studien (62), 1971. Reprinted in Immanuel Kant: Critical Assessments (eds): R.F. Chadwick. Volume III, Kant's moral and political philosophy, pp. 347369, Routledge, 1992.

Iivari, J and Koskela, E. "The PIOCO model for IS design," MIS Quarterly, (11:3), pp. 401-419, 1987.

Iivari, J. "Levels of abstraction as a Conceptual Framework for an Information Systems, " In E. D. Falkenberg and P. Lindgreen (eds): Information System Concepts: An In-depth Analysis, North-Holland, Amsterdam, 1989.

Jajodia, S. and Sandhu, R. "Solutions to the Polyinstantiation Problem," In: Information Security: An integrated Collection of Essays, (eds.): M. D. Abrahams, S. Jajodia and H. J. Podell. IEEE Computer Society Press, Los Alamitos, California, USA, 1995.

Jackson, T. P. "Love Discosoled: Meditations on Christian Charity,“ Cambridge University Press, UK, 1999.

Järvinen, P. "The new classification of research approaches," The IFIP Pink Summary - 36 years of IFIP, Edited by H, Zemanek, Laxenburg, IFIP, 1997.

Kant, I. "Kant's Gemmelte Schriften: 4. Abt. Vorlesungen über Moralphilosophie," Walter de Gruyter \& Co., Berlin, 1974.

Kant, I. "Critique of practical reason," Cambridge University Press, UK, 1997.

Kukathas, C. and Pettit, P. "Rawls - A Theory of Justice and its Critics," Stanford University Press, California, USA, 1990.

Lunt, T.F. "Polyinstantion: an inevitable part of a multilevel world," Proceedings of the IV Computer Security Foundations Workshop, IEEE Computer Security Press, 1991.

Lyytinen, K., (1987), A Taxonomic Perspective of Information Systems Development: Theoretical Constructs and Recommendations. In R.J. Boland \& R.A. Hirscheim (ed): Critical Issues in Information Systems Research, John Wiley \& Sons Ltd, Chichester, UK.

MacIntyre, A. "After virtue: A Study in Moral Theory," Second edition, London, Duckworth, UK, 1986.

Macquarrie, J and Childress, J. (eds): "A New Dictionary of Christian Ethics, " SCM Press LTD, 1986.

Niiniluoto, I. "Should technological imperatives be obeyed?" International Studies in the Philosophy of Science, (4:2), pp. 181-189, 1990.

Niiniluoto, I. " The aim and Structure of Applied Research," Erkenntnis (38), pp.1-21, 1993, Kluwer Academic Publishers. 
Outga, G., “Agape: An Ethical Analysis,” Yale University Press, UK, 1972.

Pernul, G. " Security constraint processing during multilevel secure database design," Proceedings of the 8th Annual Computer Security Applications Conference, IEEE Society Press, 1992.

Pernul, G., Tjoa A. M. and Winiwarter, W. "Modelling Data Secrecy and Integrity," Data \& Knowledge Engineering, (26), pp. 291-308, North Holland, 1998.

Raphael, D.D. "Moral Philosophy," Oxford University Press, UK, 1994.

Rawls, J. "Theory of Justice," Oxford University Press, 1972.

Ross, D. "The Right and the Good," Oxford University Press, 1930.

Siponen, M.T. "The Relevance of Software rights: An Anthology of the Divergence of Sociopolitical Doctrines," AI \& Society, 2001, vol. 15, no. 1\&2, pp. 128-148.

Siponen, M.T. \& Vartiainen, T. "Teaching End-User Ethics: Issues and a Solution Based on Universalizability" Communications of the Association for Information Systems, 2002, vol. 8, article 29.

Stevenson, C. L. "Ethics and Language," New Haven, USA, 1944.

Taylor, P.W. "Principles of Ethics - An Introduction," Dickenson publishing company, Encino, California, USA, 1975.

Thomas, G., "Christian Ethics and Moral Philosophy," Charles Scribner's Sons, New York, USA, 1955.

Warburton, N. "Philosophy: the Basics, " Second Edition. T J Press Ltd Padstow, Cornwall, UK, 1996. 